\title{
Diclofenaco por Via Muscular ou Retal Associado com Baixas Doses de Morfina Subaracnóidea para Analgesia Pós-Operatória em Cesarianas *
}

\section{Intramuscular Versus Rectal Diclofenac Associated with Low Dose Spinal Morphine for Post-Cesarean Analgesia}

\author{
Mônica Maria Siaulys Capel Cardoso, TSA ${ }^{1}$, José Carlos Almeida Carvalho, TSA ${ }^{2}$, Silvia Maria Machado Tahamtani ${ }^{3}$
}

\begin{abstract}
RESUMO
Cardoso MMSC, Carvalho JCA, Tahamtani SMM - Diclofenaco por Via Muscular ou Retal Associado com Baixas Doses de Morfina Subaracnóidea para Analgesia Pós-Operatória em Cesarianas

Justificativa e Objetivos - O diclofenaco tem sido utilizado em combinação com opióides por via subaracnóidea no controle da dor pós-operatória; entretanto, a melhor forma de sua administração não é conhecida. Este estudo avaliou a qualidade da analgesia pós-operatória de diferentes esquemas de administração de diclofenaco, em pacientes submetidas à cesariana sob raquianestesia com bupivacaína e morfina.

Método - Após o final da cirurgia, as pacientes foram distribuídas aleatoriamente em três grupos que receberam diclofenaco como se segue: G50VR ( $n=62), 50 \mathrm{mg}$ por via retal; G50IM ( $n=62), 50 \mathrm{mg}$ por via muscular e G75IM ( $n=62), 75 \mathrm{mg}$ por via muscular. A dor foi avaliada com uma escala analógica visual de $0-10 \mathrm{~cm}$ (EAV) a cada 30 minutos nas primeiras seis horas e meperidina, via venosa, foi administrada como medicação de resgate sempre que a EAV fosse igual ou maior que $3 \mathrm{~cm}$.

Resultados - No intervalo entre 30 e 150 minutos após a administração do diclofenaco, a média da intensidade de dor no grupo G50VR $(0,9 \pm 1,4 ; 1,4 \pm 1,4 ; 1,3 \pm 1,5 ; 1,3 \pm 1,2$ e $1,5 \pm$ $3,3 \mathrm{~cm})$ foi maior quando comparada com as do G50IM $(0,4 \pm$ $0,8 ; 0,5 \pm 0,8 ; 0,7 \pm 1,0 ; 0,7 \pm 1,1$ e $0,7 \pm 1,1 \mathrm{~cm})$ e G75IM $(0,4 \pm$ $0,8 ; 0,7 \pm 1,3 ; 0,7 \pm 1,1 ; 0,8 \pm 1,2$ e $0,7 \pm 1,0 \mathrm{~cm})$. A necessidade de meperidina de resgate $(43,5 \%)$ e o consumo total de meperidina (21,3 $\pm 28,9 \mathrm{mg}$ ) foram maiores no G50VR, quando comparados com G50IM (21\% e 8,2 $\pm 18,2 \mathrm{mg})$ e G75IM $(19,4 \%$ e 6,8 $\pm 16,7 \mathrm{mg}$ ).
\end{abstract}

Conclusões - Quando combinada com baixas doses de morfina subaracnóidea, a administração do diclofenaco por via

\footnotetext{
* Recebido da (Received from) Disciplina de Anestesiologia, Faculdade de Medicina da Universidade de São Paulo, Departamento de Anestesiologia, Hospital e Maternidade Santa Joana, São Paulo, SP

1. Supervisora do Serviço de Anestesia Obstétrica, Divisão de Anestesia do HCFMUSP; Anestesiologista do Hospital e Maternidade Santa Joana

2. Prof. Doutor do Serviço de Pós Graduação, Faculdade de Medicina da USP; Diretor Científico, Departamento de Anestesiologia, Centro de Estudos Santa Joana-Pró Matre

3. Anestesiologista do Hospital e Maternidade Santa Joana
}

Apresentado (Submitted) em 28 de janeiro de 2002

Aceito (Accepted) para publicação em 03 de abril de 2002

Correspondência para (Mail to):

Dra. Mônica Maria Siaulys Capel Cardoso

Avenida Lavandisca 142/21

04515-010 São Paulo, SP

(C) Sociedade Brasileira de Anestesiologia, 2002 muscular promove melhor analgesia pós-operatória que por via retal. Além disso, parece haver um efeito teto para esta droga, já que não se observam vantagens com doses superiores a $50 \mathrm{mg}$ por via muscular.

UNITERMOS: ANALGESIA, Pós-operatória; CIRURGIA, Obstétrica: cesariana; DROGAS, Antiinflamatório: diclofenaco; TÉCNICAS ANESTÉSICAS, Regional: subaracnóidea

\section{SUMMARY}

Cardoso MMSC, Carvalho JCA, Tahamtani SMM - Intramuscular Versus Rectal Diclofenac Associated with Low Dose Spinal Morphine for Post-Cesarean Analgesia.

Background and Objectives - Diclofenac has been used in combination with spinal opioids to control postoperative pain; however, the best regimen of its administration is not known. This study evaluated the quality of postoperative analgesia of different regimens of diclofenac administration, in patients submitted to Cesarean section under spinal anesthesia with bupivacaine and morphine.

Methods - After the end of surgery, patients were randomly allocated into three groups that received diclofenac as follows: G50VR $(n=62), 50 \mathrm{mg}$ rectally; $\mathrm{G} 50 \mathrm{IM}(\mathrm{n}=62), 50 \mathrm{mg}$ intramuscularly and G75IM ( $n=62), 75 \mathrm{mg}$ intramuscularly. Pain was evaluated with a $0-10 \mathrm{~cm}$ visual analog scale (VAS) every 30 minutes for six hours and rescue intravenous (iv) meperidine was administered whenever VAS $\geq 3 \mathrm{~cm}$.

Results - In the interval between 30 and $150 \mathrm{~min}$ after diclofenac administration, mean pain scores in G50VR (0.9 \pm $1.4 ; 1.4 \pm 1.4 ; 1.3 \pm 1.5 ; 1.3 \pm 1.2$ and $1.5 \pm 3.3 \mathrm{~cm})$ were higher as compared to G50IM (0.4 $\pm 0.8 ; 0.5 \pm 0.8 ; 0.7 \pm 1.0 ; 0.7 \pm 1.1$ and $0.7 \pm 1.1 \mathrm{~cm})$ and $\mathrm{G} 75 \mathrm{IM}(0.4 \pm 0.8 ; 0.7 \pm 1.3 ; 0.7 \pm 1.1 ; 0.8 \pm$ 1.2 and $0.7 \pm 1.0 \mathrm{~cm})$. The need for rescue meperidine $(43.5 \%)$ and total meperidine consumption $(21.3 \pm 28.9 \mathrm{mg})$ were higher in G50VR as compared to G50IM (21\% and $8.2 \pm 18.2 \mathrm{mg})$ and G75IM (19.4\% and $6.8 \pm 16.7 \mathrm{mg})$ respectively.

Conclusions - When associated with low doses of spinal morphine, intramuscular diclofenac offers better postoperative analgesia than the rectal route. Additionally, a ceiling effect is probably present for this drug, as no advantages were observed with doses larger than $50 \mathrm{mg}$ intramuscularly.

KEY WORDS: ANALGESIA, Postoperative; ANESTHETIC TECHNIQUES: Regional: spinal block; DRUGS, Anti-inflammatory: diclofenac; SURGERY, Obstetric: cesarean section

\section{INTRODUÇÃO}

diclofenaco é uma droga antiinflamatória não esteróide (AINE) de grande valor na analgesia pós-operatória. Estudos em analgesia pós-cesariana indicam que tanto a necessidade de opióides quanto os escores de dor podem 
ser diminuídos quando o diclofenaco é administrado em diferentes doses e por diferentes vias ${ }^{1-3}$.

As propriedades analgésicas do diclofenaco têm sido atribuídas aos seus efeitos sobre a síntese periférica de prostaglandinas. Entretanto, estudos recentes no homem e em animais sugerem que parte dessas propriedades seja devida a sua ação sobre mecanismos nociceptivos centrais que modulam a dor ${ }^{4,5}$

Está bem documentado que a duração do efeito antiinflamatório não está relacionado à concentração plasmática da droga. Em relação ao efeito analgésico, entretanto, essa relação ainda é desconhecida. Como conseqüência, a dose ea via de administração ideais ainda têm que ser determinadas e estudos que comparem a eficácia analgésica de vias de administração alternativas da mesma droga são necessários para o estabelecimento do regime terapêutico ideal.

O objetivo deste estudo é avaliar a qualidade da analgesia pós-operatória após a administração de diclofenaco pelas vias muscular e retal, em diferentes doses, em pacientes submetidas à cesariana sob raquianestesia com bupivacaína hiperbárica e baixa dose de morfina.

\section{MÉTODO}

Após aprovação das Comissões de Ética e Pesquisa e consentimento das pacientes, foram estudadas 186 gestantes, estado físico ASA I, submetidas à cesariana sob raquianestesia.

Após monitorização com eletrocardiograma, aparelho de pressão não invasiva (método oscilométrico) e oxímetro de pulso e expansão volêmica aguda com $10 \mathrm{ml} . \mathrm{kg}^{-1}$ de cristalóides, as pacientes foram submetidas à raquianestesia com $15 \mathrm{mg}$ de bupivacaína à $0,5 \%$ hiperbárica e $28 \mu \mathrm{g}$ de morfina, injetadas em 60 segundos, em $L_{2}-L_{3} / L_{3}-L_{4}$, estando a paciente na posição sentada. Qualquer redução da pressão arterial sistólica em relação aos valores de controle foi tratada com bolus de $5 \mathrm{mg}$ de efedrina. Após o final da cirurgia e $90 \mathrm{minu}$ tos após a indução da raquianestesia, as pacientes foram divididas aleatoriamente em 3 grupos que receberam: Grupo $50 \mathrm{VR}(\mathrm{n}=62), 50 \mathrm{mg}$ de diclofenaco por via retal; Grupo $50 \mathrm{IM}$ $(\mathrm{n}=62), 50 \mathrm{mg}$ de diclofenaco por via muscular e Grupo $75 \mathrm{IM}$ $(n=62), 75 \mathrm{mg}$ de diclofenaco por via muscular (injeção no glúteo em todos os casos).

A analgesia pós-operatória foi avaliada utilizando-se uma escala analógica visual de dor (EAV $0=$ sem dor e EAV $10=$ dor mais intensa possível), por um anestesiologista que não conhecia a dose e a via de administração do diclofenaco, imediatamente antes da administração da droga e a cada 30 minutos, por 6 horas. Sempre que os escores de dor fossem maior que 3 , de acordo com a EAV, as pacientes recebiam 30 mg de meperidina por via venosa. As pacientes foram mantidas na sala de recuperação pós-anestésica durante todo o tempo de estudo.

Idade, peso e altura foram comparadas usando-se ANOVA. Anecessidade de meperidina de resgate foi comparada utilizando-se o teste do Qui-quadrado. A ANOVA para medidas repetidas foi usada para comparar as médias de dor durante

Revista Brasileira de Anestesiologia

Vol. 52, Nº 6, Novembro - Dezembro, 2002 o tempo de estudo. O consumo de meperidina foi avaliado utilizando-se ANOVA de um fator e o teste de Tukey foi usado para determinar em qual grupo a diferença estava presente. Um valor de $p<0,05$ foi considerado estatisticamente significativo.

\section{RESULTADOS}

Não houve diferença significativa entre os 3 grupos em relação à idade, peso e altura das pacientes (Tabela I). No intervalo entre 30 e 150 minutos após a administração do diclofenaco, os escores médios de dor no Grupo 50 VR foram maiores quando comparados àqueles observados nos grupos 50IM e 75IM (Tabela II). Anecessidade de meperidina de resgate $(43,5 \%$ das pacientes) e o consumo de meperidina $(21,3 \pm 28,9 \mathrm{mg})$ foram maiores no Grupo 50VR quando comparado aos valores obtidos nos grupos 50IM (21\% e $8,2 \pm$ $18,2 \mathrm{mg})$ e $75 \mathrm{IM}(19,4 \%$ e $6,8 \pm 16,7 \mathrm{mg})$, respectivamente.

Tabela I - Dados Antropométricos (Média I DP)

\begin{tabular}{lccc}
\hline Grupos & $\begin{array}{c}\text { Idade (anos) } \\
\mathrm{n}=62\end{array}$ & $\begin{array}{c}\text { Peso }(\mathrm{kg}) \\
\mathrm{n}=62\end{array}$ & $\begin{array}{c}\text { Altura }(\mathrm{m}) \\
\mathrm{n}=62\end{array}$ \\
\hline $50 \mathrm{VR}$ & $25,5 \pm 4,2$ & $79,3 \pm 18,4$ & $1,61 \pm 10,2$ \\
$50 \mathrm{IM}$ & $23,5 \pm 5,2$ & $64,3 \pm 6,1$ & $1,54 \pm 6,5$ \\
$75 \mathrm{IM}$ & $28,2 \pm 6,1$ & $69,3 \pm 14,2$ & $1,55 \pm 4,4$ \\
\hline
\end{tabular}

Tabela II - Escores de Dor de Acordo com a EAV nas 6 Primeiras Horas após a Administração de Diclofenaco (Média \pm DP)

\begin{tabular}{lccc}
\hline & \multicolumn{3}{c}{ Dor $(\mathrm{cm})$} \\
\hline Tempos & $\begin{array}{c}50 \mathrm{mg} \mathrm{VR} \\
(\mathrm{n}=62)\end{array}$ & $\begin{array}{c}50 \mathrm{mg} \mathrm{IM} \\
(\mathrm{n}=62)\end{array}$ & $\begin{array}{c}75 \mathrm{mg} \mathrm{IM} \\
(\mathrm{n}=62)\end{array}$ \\
\hline T0 & $0,09 \pm 0,34$ & $0,06 \pm 0,26$ & $0,11 \pm 0,39$ \\
T30* & $0,93 \pm 1,38$ & $0,37 \pm 0,80$ & $0,42 \pm 0,78$ \\
T60* & $1,35 \pm 1,43$ & $0,52 \pm 0,84$ & $0,69 \pm 1,25$ \\
T90* & $1,31 \pm 1,48$ & $0,71 \pm 1,01$ & $0,69 \pm 1,06$ \\
T120* & $1,28 \pm 1,22$ & $0,74 \pm 1,06$ & $0,83 \pm 1,11$ \\
T150* & $1,49 \pm 3,27$ & $0,71 \pm 1,06$ & $0,67 \pm 0,97$ \\
T180 & $0,87 \pm 1,31$ & $0,53 \pm 0,81$ & $0,52 \pm 0,84$ \\
T210 & $0,60 \pm 0,87$ & $0,44 \pm 0,70$ & $0,46 \pm 0,70$ \\
T240 & $0,50 \pm 0,78$ & $0,36 \pm 0,68$ & $0,26 \pm 0,54$ \\
T270 & $0,43 \pm 0,78$ & $0,19 \pm 0,50$ & $0,22 \pm 0,55$ \\
T300 & $0,34 \pm 0,92$ & $0,19 \pm 0,50$ & $0,22 \pm 0,55$ \\
T330 & $0,36 \pm 0,82$ & $0,19 \pm 0,64$ & $0,22 \pm 0,63$ \\
T360 & $0,29 \pm 0,66$ & $0,27 \pm 0,98$ & $0,17 \pm 0,56$ \\
\hline
\end{tabular}

* $p<0,05$ dor no grupo $50 \mathrm{mg}$ VR $>$ dor nos grupos $75 \mathrm{mg}$ IM e $50 \mathrm{mg}$ IM

\section{DISCUSSÃO}

A prescrição racional de AINE no período peri-operatório é importante para se obter o melhor efeito analgésico de cada droga. A prescrição adequada começa com a seleção da dro- 
ga correta. Nas últimas três décadas tem havido grande aumento no número de AINE disponíveis. Embora eles sejam classificados no mesmo grupo de drogas, a potência relativa dos três principais efeitos terapêuticos dos AINE (antiinflamatório, analgésico e antitérmico) varia consideravelmente entre os diferentes agentes. Além disso, eles podem ter ação central direta e o equilíbrio entre os efeitos analgésicos periféricos e centrais podem diferir entre os mesmos.

O diclofenaco é um inibidor não seletivo da ciclooxigenase. É superior aos outros AINE no controle da dor pós-operatória, não só porque sua potência analgésica é maior que seu efeito antiinflamatório, mas porque é menos tóxico para o trato gastrointestinal que drogas como cetoprofeno, piroxican e indometacina ${ }^{6}$. Ele também é mais seguro para as mães que estão amamentando, já que a quantidade de diclofenaco encontrado no leite é pequena e não oferece risco para o lactente ${ }^{7}$. O diclofenaco pode ser administrado por via oral, retal ou parenteral. Idealmente, a via menos invasiva deve ser sempre escolhida. Entretanto, diferentes regimes de administração podem determinar efeitos analgésicos diferentes. Embora a via oral seja a menos invasiva, esta não foi avaliada neste estudo, já que é de valor limitado no período pós-operatório imediato, particularmente em pacientes submetidos à cirurgia abdominal. Náusea e vômito podem determinar a absorção errática, conseqüentemente reduzindo sua eficácia analgésica. Infusões venosas resultam em concentrações sangüíneas mais estáveis e permitem que se atinjam concentrações teciduais altas em poucos minutos. Entretanto, a menos que devidamente diluído, é grande a incidência de dor durante a injeção e de tromboflebite. Por esse motivo, decidimos comparar a eficácia analgésica das vias muscular e retal. A via muscular é provavelmente a mais utilizada para analgesia pós-operatória e está associada com rápidas concentrações plasmáticas terapêuticas. A via retal é uma boa via alternativa, especialmente quando a administração oral não é possível, já que não depende da absorção e do esvaziamento gástrico. Entretanto, há necessidade de discussão prévia com as pacientes, já que muitas não aceitam esta via de administração.

Neste estudo, a avaliação da eficácia analgésica de diferentes regimes de administração do diclofenaco mostrou que a via muscular foi superior à via retal no controle da dor pós-operatória. A necessidade de meperidina de resgate, o consumo de meperidina e os escores de dor pós-operatória foram maiores no grupo que recebeu diclofenaco via retal. Estes resultados estão de acordo com os obtidos por Campbell e col. ${ }^{8}$ e Jakobson e col. ${ }^{9}$, que mostraram que a administração parenteral de diclofenaco determinou melhor analgesia pós-operatória que a via oral e diferem daqueles obtidos por Hyrkas e col. ${ }^{10}$ e Moore e col. ${ }^{11}$, que observaram analgesia pós-operatória semelhante quando compararam via muscular versus retal e via muscular versus muscular, respectivamente. Entretanto, é importante notar que nos dois últimos estudos, as doses de diclofenaco foram maiores nos grupos via oral e retal e menores nos grupos via muscular. É possível que esta aparente controvérsia possa estar relacionada à farmacocinética da droga.
Em doses terapêuticas entre 25 e 150 mg, a biodisponibilidade do diclofenaco aumenta linearmente após sua administração pelas vias oral, retal e muscular. Entretanto, drogas utilizadas pelas vias oral e retal sofrem o efeito metabólico da primeira passagem pelo fígado, que reduz sua biodisponibilidade em $50 \%{ }^{12}$. É possível que, nos estudos de Hyrkas e col. ${ }^{10}$ e Moore e col. ${ }^{11}$, as doses maiores administradas nos grupos via oral e retal tenham compensado a menor quantidade de diclofenaco que atingiria a circulação sistêmica conseqüente ao efeito da primeira passagem.

Quando dose diferente de diclofenaco foi administrada pela mesma via, a muscular, não observamos diferença na eficácia analgésica entre os grupos que receberam 50 e $75 \mathrm{mg}$. Este fato sugere que a biodisponibilidade do diclofenaco esteja diretamente relacionada ao seu efeito analgésico e que exista um efeito teto acima do qual o aumento na biodisponibilidade da droga não esteja associada com melhora na qualidade da analgesia pós-operatória. Estes dados estão de acordo com os obtidos por O'Hara ${ }^{13}$ que também demonstrou efeito teto para o cetorolaco; doses maiores que $30 \mathrm{mg}$ não promoveram melhora na qualidade da analgesia pós-operatória.

A comparação adequada da eficácia analgésica de diferentes regimes de administração de diclofenaco requer modelo apropriado de estudo da dor pós-operatória. Cirurgias associadas a escores baixos de dor podem não se prestar para distinguir a eficácia analgésica de diferentes drogas por diferentes vias de administração. Nessas circunstâncias, a equivalência entre os grupos pode ser conseqüente à falta de sensibilidade intrínseca do modelo de estudo da dor. Um aumento de sensibilidade intrínseca do modelo pode ser obtido incluindo-se um grupo placebo, no qual nenhum tratamento é utilizado, ou administrando-se duas doses diferentes da mesma droga, preferencialmente pela mesma via, obtendo-se desta forma uma curva dose-resposta. Como a proposta deste estudo foi comparar a eficácia analgésica do diclofenaco, quando administrado por diferentes vias e em diferentes doses, não se incluiu um grupo controle.

Administrou-se intencionalmente morfina em associação com bupivacaína hiperbárica, já que o diclofenaco como droga única não se mostrou eficaz para controlar a dor pós-cesariana. A administração de morfina poderia ser questionada no sentido de que a analgesia obtida poderia ser determinada somente por ela. Entretanto, Cardoso e col. ${ }^{3}$. demonstraram que em pacientes submetidas à cesariana sob raquianestesia com até $100 \mu \mathrm{g}$ de morfina, a necessidade de analgésicos de resgate ocorreu em até $75 \%$ das pacientes. Em aproximadamente $25 \%$ das pacientes a morfina por via subaracnóidea, como droga isolada, foi suficiente para controlar a dor pós-operatória. Entretanto, na prática clínica, não é possível predizer quais serão essas pacientes e a associação do AINE ao opióide é justificável.

Na sala de recuperação pós-anestésica, a dor foi avaliada utilizando-se a EAV, que é um método simples, confiável e sensível de quantificação da dor ${ }^{14}$. Embora as bombas de ACP (analgesia controlada pelo paciente), que seriam a forma ideal de estudo, não tenham sido utilizadas, a avaliação 
da dor foi feita a cada 30 minutos e o analgésico de resgate estava pronto para ser administrado sempre que as pacientes acusavam dor maior que $3 \mathrm{~cm}$ na EAV. A meperidina foi escolhida como analgésico de resgate por ser medicação de uso comum no pós-operatório imediato de pacientes obstétricas. O consumo de analgésicos no pós-operatório não foi avaliado isoladamente. A qualidade da analgesia pós-operatória também incluiu os escores médios de dor e a freqüência de solicitação de analgésicos suplementares.

Embora o efeito preemptivo dos AINE seja sempre questionado, está claro que a administração pré-operatória de AINE é de interesse, já que os AINE exercem seus efeitos nos mecanismos de dor por inibição da ação da ciclooxigenase, desta forma prevenindo a produção de prostaglandinas. Dependendo da dose, via e velocidade de administração, diferentes intervalos de tempo são necessários antes que as drogas atinjam o local de ação, inibam a enzima e exerçam o efeito clínico. Os AINE não têm efeito direto na atividade das prostaglandinas que já tenham sido sintetizadas. Neste estudo, o diclofenaco não foi administrado no pré-operatório, já que se tratava de pacientes obstétricas. Segundo Willis e col. ${ }^{12}$ as concentrações plasmáticas máximas da droga são obtidas em cerca de 30 minutos, o que exporia o feto e o neonato aos seus possíveis efeitos colaterais, tais como hemorragia gástrica, hiperbilirrubinemia, disfunção renal transitória, hipertensão pulmonar e fechamento do ducto arterioso fetal. Optamos por administrar o diclofenaco 90 minutos após a instalação da raquianestesia, quando a cirurgia havia terminado em todas as pacientes e a dor ainda não estava presente.

O estudo terminou 360 minutos após a administração do diclofenaco, coincidindo com o tempo de permanência das pacientes na sala de recuperação pós-anestésica, sob supervisão direta dos anestesiologistas.

Concluindo, os resultados deste estudo demonstram que, quando combinada com baixas doses de morfina subaracnóidea, a administração do diclofenaco por via muscular promove melhor analgesia pós-operatória do que por via retal. Além disso, parece haver um efeito teto para esta droga, quando utilizada no controle da dor pós-operatória imediata; não se observam vantagens com doses superiores a $50 \mathrm{mg}$ por via muscular.

\section{Intramuscular Versus Rectal Diclofenac Associated with Low Dose Spinal Mor- phine for Post-Cesarean Analgesia}

Mônica Maria Siaulys Capel Cardoso, TSA, M.D., José Carlos Almeida Carvalho, TSA, M.D., Silvia Maria Machado Tahamtani, M.D.

\section{INTRODUCTION}

Diclofenac is a nonsteroidal anti-inflammatory drug (NSAID) of great value in postoperative analgesia. Studies in post-ce- sarean analgesia indicate that both opioid requirements and pain scores may be reduced when diclofenac is administered by different routes and doses ${ }^{1-3}$.

Diclofenac analgesic properties have been attributed to its effects on the peripheral synthesis of prostaglandins. However, recent animal and human studies suggest that part of such properties may be due to its action on central antinociceptive mechanisms that modulate pain ${ }^{4,5}$.

It is well documented that the duration of the anti-inflammatory effect is not related to the plasma concentration of the drug. As regards the analgesic effect, this is yet unknown. As a consequence, the optimal dose and route of its administration has yet to be determined and studies that compare analgesic efficacy of alternative routes of administration of the same drug are necessary for the establishment of an ideal therapeutic regimen.

The purpose of this study is to evaluate the quality of postoperative analgesia after the administration of diclofenac in different doses and routes in patients submitted to cesarean section under spinal anesthesia with hyperbaric bupivacaine and low dose morphine.

\section{METHODS}

After Institutional approval and written informed consent, 186 ASA I pregnant patients submitted to cesarean section under spinal anesthesia were studied.

After monitoring with ECG, non-invasive blood pressure and pulse oximetry and acute volume expansion with $10 \mathrm{ml}^{\mathrm{kg}} \mathrm{kg}^{-1}$ of crystalloid, patients were submitted to spinal anesthesia with $15 \mathrm{mg}$ of $0.5 \%$ hyperbaric bupivacaine and $28 \mu \mathrm{g}$ of morphine administered in 60 seconds in $L_{2}-L_{3}-L_{3}-L_{4}$. Reductions of blood pressure values greater than $20 \%$ of the control value were treated with $5 \mathrm{mg}$ bolus of ephedrine. After the end of the surgery and 90 minutes following the induction of spinal anesthesia, patients were randomly allocated into three groups that received: Group 50VR ( $=62), 50 \mathrm{mg}$ of diclofenac rectally; Group 50IM ( $n=62) 50$ mg of diclofenac intramuscularly and Group $75 \mathrm{IM}, 75 \mathrm{mg}$ of diclofenac intramuscularly (gluteus injection for all patients).

Postoperative pain was evaluated using the visual analogue scale of pain (VAS: $0=$ no pain and $10 \mathrm{~cm}=$ worst pain possible) by a blinded anesthesiologist immediately before the administration of the drug and then every 30 minutes for six hours. Whenever pain scores were greater than $3 \mathrm{~cm}$ according to VAS, patients received $30 \mathrm{mg}$ of IV meperidine. Patients were kept in the recovery room throughout the study. Age, weight and height were compared using ANOVA. The need for rescue analgesics was compared using the Chi-square test. ANOVA for repeated evaluations were used to compare mean pain scores throughout the study period. Meperidine consumption was evaluated using ANOVA of one factor and the Tukey test was used to determine in which group the difference was present. A p value $<0.05$ was considered significant. 


\section{RESULTS}

There were no statistically significant differences among the 3 groups with respect to age, height and weight (Table I). In the interval between 30 and 150 minutes after diclofenac administration, the mean pain scores in group 50VR were higher as compared to those obtained in groups 50IM and $75 \mathrm{IM}$ (Table II). The need for rescue analgesics (43.5\% of patients) and meperidine consumption $(21.3 \pm 28.9 \mathrm{mg})$ were higher in group 50VR as compared to values obtained in groups 50IM (21\% and $8.2 \pm 18.2 \mathrm{mg})$ and $75 \mathrm{IM}(19.4 \%$ and $6.8 \pm 16.7 \mathrm{mg}$ ) respectively.

Table I - Anthropometric Data (Mean \pm SD)

\begin{tabular}{lccc}
\hline Groups & $\begin{array}{c}\text { Age (years) } \\
\mathrm{n}=62\end{array}$ & $\begin{array}{c}\text { Weight }(\mathrm{kg}) \\
\mathrm{n}=62\end{array}$ & $\begin{array}{c}\text { Height }(\mathrm{m}) \\
\mathrm{n}=62\end{array}$ \\
\hline $50 \mathrm{VR}$ & $25.5 \pm 4.2$ & $79.3 \pm 18.4$ & $1.61 \pm 10.2$ \\
$50 \mathrm{IM}$ & $23.5 \pm 5.2$ & $64.3 \pm 6.1$ & $1.54 \pm 6.5$ \\
$75 \mathrm{IM}$ & $28.2 \pm 6.1$ & $69.3 \pm 14.2$ & $1.55 \pm 4.4$ \\
\hline
\end{tabular}

Table II - Pain Scores According to VAS in the First Six Hours following Diclofenac Administration (Mean \pm SD)

\begin{tabular}{lccc}
\hline Times & $\begin{array}{c}50 \mathrm{mg} \mathrm{VR} \\
(\mathrm{n}=62)\end{array}$ & $\begin{array}{c}50 \mathrm{mg} \mathrm{IM} \\
(\mathrm{n}=62)\end{array}$ & $\begin{array}{c}75 \mathrm{mg} \mathrm{IM} \\
(\mathrm{n}=62)\end{array}$ \\
\hline T0 & $0.09 \pm 0.34$ & $0.06 \pm 0.26$ & $0.11 \pm 0.39$ \\
T30* & $0.93 \pm 1.38$ & $0.37 \pm 0.80$ & $0.42 \pm 0.78$ \\
T60* & $1.35 \pm 1.43$ & $0.52 \pm 0.84$ & $0.69 \pm 1.25$ \\
T90* & $1.31 \pm 1.48$ & $0.71 \pm 1.01$ & $0.69 \pm 1.06$ \\
T120* & $1.28 \pm 1.22$ & $0.74 \pm 1.06$ & $0.83 \pm 1.11$ \\
T150* & $1.49 \pm 3.27$ & $0.71 \pm 1.06$ & $0.67 \pm 0.97$ \\
T180 & $0.87 \pm 1.31$ & $0.53 \pm 0.81$ & $0.52 \pm 0.84$ \\
T210 & $0.60 \pm 0.87$ & $0.44 \pm 0.70$ & $0.46 \pm 0.70$ \\
T240 & $0.50 \pm 0.78$ & $0.36 \pm 0.68$ & $0.26 \pm 0.54$ \\
T270 & $0.43 \pm 0.78$ & $0.19 \pm 0.50$ & $0.22 \pm 0.55$ \\
T300 & $0.34 \pm 0.92$ & $0.19 \pm 0.50$ & $0.22 \pm 0.55$ \\
T330 & $0.36 \pm 0.82$ & $0.19 \pm 0.64$ & $0.22 \pm 0.63$ \\
\hline
\end{tabular}

${ }^{*} \mathrm{p}<0.05$ pain in group $50 \mathrm{mg}$ VR $>$ pain in groups $75 \mathrm{mg} \mathrm{IM}$ and $50 \mathrm{mg} \mathrm{IM}$

\section{DISCUSSION}

Rational prescription of NSAIDs in the perioperative period is important to obtain the best analgesic effect of each drug. Adequate prescription begins with the selection of the correct drug. Over the last 3 decades there has been a dramatic increase in the number of new NSAIDs available and although they are classified in the same group of drugs, the relative potency of the three main therapeutic effects of NSAIDs (anti-inflammatory, analgesic, antithermic) vary considerably among individual agents. Additionally, they may have direct central activity and the balance between peripheral and central analgesic effects may differ among agents.
Diclofenac is a non-selective inhibitor of cyclooxigenase. It is superior to other NSAIDs to control postoperative pain because it not only has a greater analgesic potency in relation to its anti-inflammatory effects but it is also less toxic to the gastrointestinal tract than drugs such as ketoprofen, piroxicam and indomethacin ${ }^{6}$. It is also safe for the breastfeeding women, as the amount of diclofenac found in the milk is small and offers no risk for the nursing infant ${ }^{7}$.

Diclofenac may be administered by the oral, rectal and parenteral route. Ideally, the least invasive route should always be chosen. However, different regimens of administration may determine different analgesic effects. Although the oral route is the least invasive, it was not evaluated in this study, as it is of limited value in the early postoperative period, particularly in patients submitted to abdominal surgery. Nausea and vomiting can make absorption of the drug erratic and so reduce its analgesic efficacy. Intravenous infusions result in more stable blood concentrations and enable high tissue levels to be achieved within a few minutes. However, unless diluted properly beforehand, pain during injection of the drug and thrombophlebitis may commonly occur. So, we decided to compare the analgesic efficacy of the rectal and intramuscular routes. The intramuscular route is probably the most commonly used for postoperative analgesia and it is associated fast therapeutic plasma concentrations. Rectal administration is a good alternative route, especially when oral administration is not possible, as it does not rely on gastric absorption and emptying. However, previous discussion with patients is necessary, as many will not agree with the route of administration.

In this study, the evaluation of the analgesic efficacy of different regimens of administration of diclofenac showed that the intramuscular route was superior to the rectal route to control postoperative pain. The need for rescue analgesics, analgesic consumption and mean postoperative pain scores were higher in the group that received diclofenac rectally.

These results are in agreement with the ones obtained by Campbell et al. ${ }^{8}$ and Jakobson et al. ${ }^{9}$ that showed that the parenteral administration of diclofenac was associated with better postoperative analgesia than the oral route, and differ from the ones obtained by Hyrkas et al ${ }^{10}$ and Moore et al. ${ }^{11}$, who found equivalent postoperative analgesia when they compared the oral vs intramuscular and the rectal vs intramuscular administration of diclofenac respectively. However, it is important to notice that in the last two studies, diclofenac doses administered were higher in the oral and rectal groups and lower in the intramuscular groups. It is possible that this apparent controversy may be related to the pharmacokinetics of the drug.

In therapeutic doses of $25-150 \mathrm{mg}$, the bioavailability of diclofenac increases linearly following its administration by the oral, rectal and intramuscular routes. However, drugs used by the oral and rectal routes undergo the first-pass metabolism effect, which reduces its bioavailabilty in $50 \%{ }^{12}$. It is possible that in the studies done by Hyrkas et al. ${ }^{10}$ and Moore et al. ${ }^{11}$, the larger doses given in the oral and rectal groups may have compensated for a reduced amount of diclofenac 
that would reach the systemic circulation due to the first-pass effect.

When different doses of diclofenac were administered by the same route, no differences in the analgesic efficacy were observed between groups that received 50 and $75 \mathrm{mg}$ of diclofenac intramuscularly. This fact suggests that the bioavailabilty of diclofenac may be directly correlated with its analgesic efficacy and that there is a ceiling effect, above which increases in the bioavailabilty of the drug are not associated with improvements in the quality of postoperative analgesia. These data are in agreement with the ones obtained by O'Hara ${ }^{13}$ who also demonstrated a ceiling effect for ketorolac, when the administration of doses higher than 30 mg were not associated with an improvement in the quality of postoperative analgesia.

Adequate comparison of the analgesic efficacy of different regimens of diclofenac administration requires an appropriate model of postoperative pain. Surgeries associated with low postoperative pain scores may not serve to distinguish analgesic efficacy following the administration of a specific drug by different routes and in different doses. Under these circumstances, equivalency among groups may be due to a lack in the internal sensitivity of the pain model. An index of internal sensitivity may be obtained by including a placebo group, in which no treatment is used or administering two different doses of the same drug, preferably by the same route in order to obtain a dose-response curve. As the purpose of this study was to compare the analgesic efficacy of diclofenac, when administered by different routes and doses, a control group was not included.

Spinal morphine was intentionally administered in association with hyperbaric bupivacaine, as diclofenac alone was not sufficient to control postoperative pain following cesarean section. On the other hand, with the addition of spinal morphine, one may question the validity of administering diclofenac to control post-cesarean pain, as analgesia might be solely attributed to the action of that opioid. However, Cardoso et al. ${ }^{3}$ demonstrated that in patients submitted to cesarean section under spinal anesthesia with up to $100 \mu \mathrm{g}$ of morphine, the need for rescue analgesics occurred in up to $75 \%$ of the patients. In approximately $25 \%$ of patients, spinal morphine alone was sufficient to control postoperative pain. However, in clinical practice, it is not possible to predict such patients and the association of opioid and NSAIDs is clinically justifiable.

In the recovery room, pain was evaluated using the visual analogue scale, which is a sensitive, reliable and simple method to quantify postoperative pain ${ }^{14}$. Although patient-controlled analgesia devices, which should be the ideal method of study, were not used, postoperative pain was assessed every 30 minutes, and rescue analgesics were ready to be administered whenever patients reported pain higher than $3 \mathrm{~cm}$ (VAS). Meperidine was chosen as the rescue analgesic, as it is commonly administered in the perioperative period of obstetric patients. Analgesic consumption in the postoperative period was not evaluated alone. The quality of postoperative analgesia also included mean pain scores and the need for rescue analgesics.

Although the preemptive effect of NSAIDs is always questioned, it is clear that the preoperative administration of NSAIDs is of interest, since NSAIDs exert their effects on the pain pathways by inhibiting the action of the cyclooxigenase, thus preventing the production of prostaglandins. Depending on the dose, route and rate of administration, different time intervals are required before the drugs reach their site of action, inhibit the enzyme and exert a clinical effect. NSAIDs have no direct effect on the activity of prostaglandins that have already been synthesized. In this study, diclofenac was not administered preoperatively, as we were treating obstetric patients. According to Willis et al. ${ }^{12}$ peak plasma concentrations of the drug are reached in around 30 minutes, exposing the neonate to its possible side effects such as gastric hemorrhage, hyperbilirubinemia, transient renal dysfunction, pulmonary hypertension and fetal ductus arteriosus closure. We choose to administer diclofenac 90 minutes after spinal anesthesia, when surgery was completed in all patients and pain was not yet present.

The study ended at 360 minutes after diclofenac administration as it corresponds with the period that patients stay in the recovery room and under direct supervision of the anesthesiologists.

In conclusion, the results of this study demonstrate that while combined with small doses of spinal morphine, the intramuscularly administration of diclofenac offers better postoperative analgesia than the rectal route. Additionally, it seems that there is a ceiling effect for this drug, used for immediate postoperative pain management; no advantages are observed with doses larger than $50 \mathrm{mg}$ intramuscularly.

\section{REFERÊNCIAS - REFERENCES}

01. Luthman J, Kay NH, White JB - The morphine sparing effect of diclofenac sodium following cesarean section under spinal anesthesia. Int J Obstet Anesth, 1994;3:82-86.

02. Dennis AR, Leeson-Payne CG, Hobbs GJ - Analgesia after cesarean section. The use of diclofenac as an adjunct to spinal morphine. Anaesthesia, 1995;50:297-299

03. Cardoso MMSC, Carvalho, JCA, Amaro AR et al - Small doses of spinal morphine combined with systemic diclofenac for postoperative analgesia after cesarean delivery. Anesth Analg, 1998;86:538-541.

04. McCormack K - The spinal actions of nonsteroidal anti-inflammatory drugs and the dissociation between their anti-inflammatory and analgesic effects. Drugs, 1994;47:28-45.

05. Bjorkman R - Central antinociceptive effects of nonsteroidal anti-inflammatory drugs and paracetamol. Acta Anaesthesiol Scand, 1995;39:1-44.

06. Peloso PM - Strategies and practice for use of nonsteroidal anti-inflammatory drugs Scand J Rheumatol, 1996;105:29-48.

07. Ostensen M, Husby G - Antirheumatic drug treatment during pregnancy and lactation. Scand J Rheumatol, 1985;14:1-7.

08. Campbell WI, Kendrick R, Patterson C - Intravenous diclofenac sodium. Does its administration before operation suppress postoperative pain? Anaesthesia, 1990;45:763-766. 
09. Jakobson J, Rane K, Davidson S - Intramuscular NSAID reduces postoperative pain after minor outpatient anesthesia. Eur J Anaesth, 1996;13:67-71.

10. Hyrkas T, Ylipaavalniemi P, Oikarinen VJ et al - Postoperative pain prevention by a single-dose formulation of diclofenac producing a steady plasma concentration. J Oral Maxillofac Surg, 1992;50:124-127

11. Moore AP, Thorpe JA, Mulley BA et al - Which diclofenac form is best? Post-thoracotomy pain: intramuscular vs rectal administration of diclofenac. Hosp Pharm Pract, 1993;431-432.

12. Willis JV, Kendall MJ, Flinn RM et al - The pharmacokinetics of diclofenac sodium following intravenous and oral administration. Eur J Clin Pharmacol, 1979;16:405-410.

13. O'Hara DA, Fragen RJ, Kinzer M et al - Ketorolac tromethamine as compared with morphine sulfate for treatment of postoperative pain. Clin Pharmacol Ther, 1987;41:556-561.

14. Scott J, Huskisson EC - Graphic representation of pain. Pain, 1976;2:175-184.

\section{RESUMEN}

Cardoso MMSC, Carvalho JCA, Tahamtani SMM - Diclofenaco por Vía Muscular o Rectal Asociado con Bajas Dosis de Morfina Subaracnóidea para Analgesia Pós-Operatoria en Cesáreas

Justificativa y Objetivos - El diclofenaco ha sido utilizado en combinación con opioides por vía subaracnóidea en el control del dolor pós-operatorio; mientras que, la mejor forma de su administración no es conocida. Este estudio evaluó la calidad de la analgesia pós-operatoria de diferentes esquemas de administración de diclofenaco, en pacientes sometidas a cesárea bajo raquianestesia con bupivacaína y morfina.

Método - Después del final de la cirugía, las pacientes fueron distribuidas aleatoriamente en tres grupos que recibieron diclofenaco como se sigue: G50VR ( $n=62)$, 50 mg por vía rectal; G50IM ( $n=62), 50$ mg por vía muscular y G75IM $(n=62), 75$ mg por vía muscular. El dolor fue evaluado con una escala analógica visual de $0-10 \mathrm{~cm}$ (EAV) a cada 30 minutos en las primeras seis horas y meperidina, vía venosa, fue administrada como medicación de rescate siempre que la EAV fuera igual o mayor que $3 \mathrm{~cm}$.

Resultados - En el intervalo entre 30 y 150 minutos después de la administración de diclofenaco, la media de la intensidad de dolor en el grupo G50VR $(0,9 \pm 1,4 ; 1,4 \pm 1,4 ; 1,3 \pm 1,5 ; 1,3 \pm 1,2$ y $1,5 \pm 3,3 \mathrm{~cm}$ ) fue mayor cuando comparada con las del G50IM $(0,4 \pm 0,8 ; 0,5 \pm 0,8 ; 0,7 \pm 1,0 ; 0,7 \pm 1,1$ y $0,7 \pm 1,1 \mathrm{~cm})$ y $\mathrm{G} 75 \mathrm{IM}$ $(0,4 \pm 0,8 ; 0,7 \pm 1,3 ; 0,7 \pm 1,1 ; 0,8 \pm 1,2$ y $0,7 \pm 1,0 \mathrm{~cm}) . \mathrm{La}$ necesidad de meperidina de rescate $(43,5 \%)$ y el consumo total de meperidina $(21,3 \pm 28,9 \mathrm{mg})$ fueron mayores en el G50VR, cuando comparados con G50IM (21\% y 8,2 $\pm 18,2 \mathrm{mg}$ ) y G75IM $(19,4 \%$ y $6,8 \pm 16,7 \mathrm{mg})$.

Conclusiones - Cuando combinada con bajas dosis de morfina subaracnóidea, la administración de diclofenaco por vía muscular promueve mejor analgesia pós-operatoria que por vía rectal. Después de eso, parece haber un efecto techo para esta droga, ya que no se observan ventajas con dosis superiores a $50 \mathrm{mg}$ por vía muscular. 